\title{
A Single-center Experience of Clinical Outcomes of Surgical Management for Rectocele Disease
}

\section{Rektosel Hastalığının Cerrahi Tedavisi ve Klinik Sonuçlarımız}

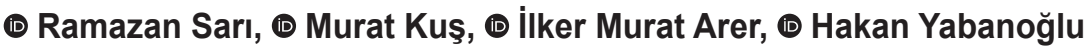 \\ Başkent University, Adana Dr. Turgut Noyan Practise and Research Center, Clinic of General Surgery, Adana, Turkey
}

\section{IIIIIIII| ABSTRACT}

Aim: Different surgical management options have been described for rectocele disease. However, there is no consensus on the best surgical technique and mesh use. In this study, we present the clinical outcomes of patients who received surgical management for rectocele disease.

Method: In our study, we analyzed the files of 78 patients who underwent surgery for rectocele between January 2002 and December 2018 . We retrospectively reviewed the treatment outcomes and clinical and demographic characteristics of these patients.

Results: The mean age of the patients was 52 (range=31-88) years and the mean parity was 3 (range=1-11). The most common complaints were constipation and defecation difficulties. The diagnosis of rectocele was confirmed by a physical examination in 58 patients ( $75 \%$ ) and confirmed by defecography in 20 patients (25\%). Primary repair was performed in 72 patients (92\%), and polypropylene mesh repair was performed with a perineal approach in six patients (8\%). Hemorrhage and infection were seen as early complications in only five patients (6.4\%). The mean hospital stay was 1.6 (range=1-11) days. The mean follow-up was 54 (range=3-218) months. There was a recurrence in two patients $(2.5 \%)$.

Conclusion: Rectocele can be successfully treated with low morbidity rates when properly diagnosed and managed by appropriate specialists. Factors such as coexisting pelvic floor diseases, age of the patient, and whether the patient is in the reproductive period should be considered when choosing the appropriate surgical technique. Also, clinicians should keep in mind that rectocele is preventable and that incidence can be reduced by lifestyle changes.

Keywords: Rectocele, surgical treatment, obstructive defecation

\section{|IIIIIII| ÖZ}

Amaç: Rektosel hastalığın tedavisinde birçok farklı cerrahi teknik tanımlanmıştır. Ancak altın standart yönteminin ne olacağı ve yama kullanımı konusunda henüz bir fikir birliği yoktur. Çalışmamızda rektosel nedeniyle farklı tekniklerle ameliyat ettiğimiz hastalarımızın klinik tedavi sonuçlarını sunmayı amaçladık.

Yöntem: Çalışmamızda Ocak 2002 ve Aralık 2018 tarihleri arasında rektosel tanısıyla ameliyat edilen 78 hastanın dosyaları tarandı. Klinik ve demografik bilgileri ile tedavi sonuçları retrospektif olarak değerlendirildi.

Bulgular: Hastaların yaş ortalaması 52 (31-88), ortalama doğum sayısı 3 (1-11). En sık başvuru şikayeti kabızlık ve defekasyonda zorluk idi. Fiziki muayenede 58 (\%75) hastada rektosel saptandı ve 20 (\%25) hastada defekografi ile doğrulandı. Yetmiş iki (\%92) hastaya transvajinal, transanal veya perineal yaklaşımlarla primer onarım uygulanırken $6(\% 8)$ hastaya perineal yaklaşımla polipropilen mesh onarımı uygulandı. Erken dönemdeki komplikasyonlara bakıldığında sadece $5(\% 6,4)$ hastada kanama ve enfeksiyon görüldü. Hastanede yatış süresi ortalama 1,6 (1-11) gün idi. Ortalama takip süresi 54 (3-218) ay olup; 2 (\%2,5) hastada nüks görüldü.

Sonuç: Rektosel doğru tanı ve uygun tedavi planı konu ile ilgili spesifik cerrahlar tarafından yapıldığında düşük morbidite oranı ile başarılı bir şekilde tedavi edilebilmektedir. Cerrahi teknik seçiminde rektosele eşlik eden ek pelvik taban hastalıkları, hastaların yaşı ve reprodüktif dönemde olmaları gibi bireysel faktörler göz önünde bulundurulmalıdır. Rektoselin belli oranda önlenebilir bir hastalık olduğu akıldan çıkarılmamalı ve yaşam tarzı değişiklikleri ile görülme sıklığının azaltılabileceği unutulmamalıdır.

Anahtar Kelimeler: Rektosel, cerrahi tedavi, obstrüktif defekasyon

The abstract of this study was presented as a poster presentation (P-075) at the $17^{\text {th }}$ Turkish Colon and Rectal Surgery Congress held between 9-13 April 2019 in Antalya.

Address for Correspondence/Yazışma Adresi: Ramazan Sarı MD,

Başkent University, Adana Dr. Turgut Noyan Practise and Research Center, Clinic of General Surgery, Adana, Turkey

Phone: +90 5056294662 E-mail: sariramazan71@gmail.com ORCID ID: orcid.org/0000-0003-3492-9953

Received/Geliş Tarihi: 28.06.2019 Accepted/Kabul Tarihi: 18.07.2019

${ }^{\circ}$ Copyright 2019 by Turkish Society of Colon and Rectal Surgery

Turkish Journal of Colorectal Disease published by Galenos Publishing House. 


\section{Introduction}

Rectocele is defined as the prolapse of the anterior rectal wall from recto-vaginal fascia or the herniation into the posterior vagina. The prevalence in women is $0.4 \%$. It is especially seen in multiparous and older women. ${ }^{1}$ However, in a study conducted with a limited number of patients, the incidence of rectocele in healthy and asymptomatic women was reported to be $93 \% .^{2}$ This situation, which may cause deterioration in the quality of life of the patients and severe problems in their social life, presents with symptoms such as constipation, defecation difficulty, and feeling of not fully emptying. Rectocele may present as an isolated disease and may also accompany many pelvic floor diseases. Although anamnesis and physical examination are usually sufficient for the diagnosis, defecography is currently the most reliable diagnostic method, which allows to dynamic visualization of the shape, size, length, and depth of the rectocele to confirm the diagnosis. ${ }^{3}$ Treatment decision is based on whether the disease is symptomatic or not, and the size of the rectocele. Many different surgical techniques have been described in surgical treatment, such as transanal, transperineal, transvaginal, and transabdominal approaches. However, a gold standard treatment method is still undefined. Also, there is no consensus on the use of meshes in repair. In this study, we aimed to present the results of clinical treatment in patients who underwent surgery with the diagnosis of rectocele.

\section{Materials and Methods}

In this study, the files of 78 patients who underwent surgery with the diagnosis of rectocele between January 2002 and December 2018 were analyzed retrospectively. In the majority of patients, the diagnosis was made after the physical examination of the clinician, and the diagnosis was confirmed by defecography in some patients. Additional investigations such as colonoscopy and pelvic magnetic resonence imaging (MRI) were requested for differential diagnosis in eligible patients. All patients were female. Patients were evaluated in terms of age, comorbidity, the number of deliveries, previous pelvic floor surgery, complaints, physical examination findings, defecography, and/or additional radiological tests, if any, surgical technique and duration, length of hospitalization, complication, postoperative control, and recurrence.

\section{Surgical Technique}

All patients received 1 gram intravenous cefazolin for prophylaxis 30 minutes before the operation. Empirical antibiotic treatment was continued in some patients postoperatively. The patients were prepared in the lithotomy position, and the surgical procedure was performed under general anesthesia in all patients. In the anterior transvaginal repair technique, the posterior vaginal mucosa was cut to the posterior fornix, and a V-shaped flap was formed. The loose recto-vaginal septum was exposed. Plication was performed with interrupted ethibond sutures from posterior fornix to inferior, and reinforcement was provided with continuous suture technique. The vaginal mucosa was closed with continuous sutures. The rectum was checked by a digital examination. For the perineal repairs, a transverse incision was performed, and the local anesthetic was injected with saline diluted with adrenaline behind the posterior vaginal wall. Posterior fornix was reached after sharp and blunt dissection. The rectocele width and localization were determined anatomically by rectal examination. For primary repair, plication was performed with absorbable suture material, and the layers were approached. For mesh repair, polypropylene mesh was prepared to fit the defect and was laid in this area, and no fixation was made. Following hemostasis, the perineal incision was closed primarily, and the operation was terminated. Since the present study consists of retrospective data, the estimation of the degree of prolapse is based on physical examination and surgery notes. According to the International Continence Society staging system, it is understood that patients have stage 1 or more disease (Table 1). In the evaluation of post-operative symptoms, patient feedback was taken into consideration, and no scale was used for evaluation. The effect of advanced age and the number of vaginal births on the development of rectocele disease was investigated. Recurrence and complication rates of patients with isolated rectocele were compared to patients who underwent other pelvic floor surgery in addition to rectocele repair. Four different surgical techniques were applied to each patient, and each group was examined in terms of recurrence and complications.

\section{Statistical Analysis}

The Statistical Package for Social Sciences (SPSS) 17.0 program was used for statistical analysis to evaluate the demographic and clinical data of the patients and to interpret the results. Categorical measurements were summarized as

Table 1. International Continence Society pelvic organ prolapse quantification system

$\begin{array}{ll}\text { Stage } 0 & \text { No prolapse } \\ \text { Stage } 1 & \text { Greater than } 1 \mathrm{~cm} \text { above the hymen } \\ \text { Stage } 2 & \begin{array}{l}1 \mathrm{~cm} \text { or less proximal or distal to the plane of the } \\ \text { hymen } \\ \text { Greater than } 1 \mathrm{~cm} \text { below the plane of the hymen, } \\ \text { but protruding no farther than } 2 \mathrm{~cm} \text { less than the } \\ \text { total vaginal length (Example; incomplete vaginal } \\ \text { prolapse) }\end{array} \\ \text { Stage } 3 & \text { Eversion of the lower genital tract is complete }\end{array}$


numbers and percentages, and continuous measurements were summarized as mean and standard deviation (median and minimum-maximum where necessary). Kaplan-Meier method was used for the survival curve.

\section{Results}

The mean age of the patients was 52 years (range $=31-88$ ), and the number of previous births was 3 (range=1-11). Thirty-two (41\%) patients had various chronic diseases such as hypertension, diabetes, and so on. Thirteen patients had previously undergone pelvic or perianal surgery for non-rectocele reasons. The most common presenting complaint was constipation and difficulty in defecation with 22 patients (28\%). Complaints and rates of admission in other patients are presented in Table 2. Four patients (5\%) had non-specific complaints, and four patients (5\%) had no complaints due to rectocele and were noticed

Table 2. Demographic and clinical characteristics of patients

\begin{tabular}{|c|c|}
\hline Mean age (years) & $52($ range $=31-88)$ \\
\hline Number of births & $3($ range $=1-11)$ \\
\hline $\begin{array}{l}\text { Additional disease } \\
\text { (with/without) }\end{array}$ & $32 / 46$ \\
\hline $\begin{array}{l}\text { Previous surgery } \\
(n=13)\end{array}$ & $\begin{array}{l}\text { Cystocele surgery: } 4 \text { patients } \\
\text { Sacrocolpopexy: } 3 \text { patients } \\
\text { TAH-BSO: } 3 \text { patient } \\
\text { Hemorrhoidectomy: } 2 \text { patients } \\
\text { Rectocele repair: } 1 \text { patient }\end{array}$ \\
\hline $\begin{array}{l}\text { The presenting } \\
\text { symptoms (n\%) }\end{array}$ & $\begin{array}{l}\text { Constipation and difficulty in defecation: } \\
22 \text { patients ( } 28 \%) \\
\text { Prolapse of the uterus: } 18 \text { patients }(23 \%) \\
\text { Cystocele symptoms: } 18 \text { patients ( } 23 \%) \\
\text { Other: } 16 \text { patients ( } 21 \%) \\
\text { None: } 4 \text { patients ( } 5 \%)\end{array}$ \\
\hline Repair type (n\%) & $\begin{array}{l}\text { Anterior transvaginal: } 65 \text { patients }(83 \%) \\
\text { Transperineal mucosal flap: } 6 \text { patients } \\
(8 \%) \\
\text { Perineal polypropylene mesh: } 6 \text { patients } \\
(8 \%) \\
\text { Posterior transanal: } 1 \text { patient ( } 1 \%)\end{array}$ \\
\hline Complication $(\mathrm{n}=5)$ & $\begin{array}{l}3 \text { wound infection } \\
2 \text { post-op bleeding }\end{array}$ \\
\hline $\begin{array}{l}\text { Duration of hospital } \\
\text { stay (days) }\end{array}$ & $1.6($ range $=1-11)$ \\
\hline Recurrence & $2(2.5 \%)$ \\
\hline Follow-up (months) & $54(3-218)$ \\
\hline
\end{tabular}

TAH-BSO: Total abdominal hysterectomy-bilateral salpingooophorectomy during the operation. On physical examination, rectocele was detected in 58 (75\%) patients, and 20 patients had no specific physical examination findings. All of the 20 patients (25\%) who underwent defecography had various degrees of rectocele findings. Nineteen patients (24\%) were operated by general surgery clinic, and 59 patients (76\%) were operated by obstetrics and gynecology clinic. Seventy-two (92\%) patients underwent primary repair via transvaginal, transanal, or perineal approaches. Six patients (8\%) who underwent surgery in the general surgery clinic underwent polypropylene mesh repair with a perineal approach. All patients operated by gynecology clinic underwent primary repair with the transvaginal approach. Regarding patients operated by general surgery clinic, six $(8 \%)$ had anterior repair by transvaginal approach, six (8\%) had perineal polypropylene mesh repair, six (8\%) had transperineal flap method, and one (1\%) had posterior transanal repair. Fifty patients $(64 \%)$ underwent pelvic floor surgery for another reason, and additionally, rectocele repair was performed. The mean operative time was 75 minutes. Operative time was significantly higher in patients who had co-session pelvic floor surgery. Bleeding and infection were seen in only five patients $(6.4 \%)$ in the early period. Four of these patients were patients who also underwent pelvic floor surgery. The mean hospital stay was 1.6 days (range $=1-11$ ). In the post-operative outpatient controls, 61 patients (78\%) did not have any complaints, and the chief complaints in the remaining patients were urinary complaints, constipation, and pain at the incision site. The mean follow-up period was 54 months (range=3-218), and recurrence was seen in two patients $(2.5 \%)$. One of them was a patient who underwent posterior transanal repair, and the other had transvaginal primary repair. Clinical and demographic data of the patients are presented in detail in Table 2 .

\section{Discussion}

Rectocele with asymptomatic or mild symptoms is an anatomical change and is not reflected in the clinic except some morphological changes that are not accepted pathological in defecation. It is mostly observed in multiparous and elderly women, and it is stated in the literature that the number of vaginal births is the primary risk factor causing rectocele. ${ }^{4}$ Recurrent vaginal births lead to weakness due to high pressure, wear, and decrease in support in the recto-vaginal septum. ${ }^{5}$ In our study, the mean number of vaginal births was 3, supporting the literature. The main symptoms seen in the clinic are common complaints in obstructive defecation syndromes such as constipation, difficulty in defecation, incomplete emptying, hand-assisted emptying. ${ }^{6}$ Our patients with isolated rectocele had similar complaints. A scoring system 
was developed by Watson et al. ${ }^{7}$ (Table 3 ) according to the frequency of clinical symptoms such as the frequency of digitation, the severity of straining, the feeling of inadequate discharge, and the vaginal mass. Changes in these scores before and after treatment can be evaluated and commented on the effectiveness of the method. However, the data in our study did not provide a detailed assessment in this respect. Sometimes the diagnosis can be delayed for various reasons. These delays can be caused by delayed hospital visits due to social reasons (embarrassment, etc.), lack of assistance from specific surgical departments, or insufficient experience of the physician concerned. The weakened and worn rectovaginal septum, together with pelvic floor disease, may also contribute to rectocele formation. In our study, more than half of the patients underwent rectocele repair during pelvic floor surgery. In these patients, both the operative time and length of hospitalization were significantly higher than in isolated cases as expected. Also, the majority of the patients with complications were these patients. When these results are evaluated, we think that the surgical treatment of isolated rectoceles can be performed mostly ambulatory and with a low complication rate. In our study, symptoms of the disease were significant only in all patients with a rectocele. However, asymptomatic rectocele was detected in four of the patients who underwent pelvic floor surgery, and primary repair was performed with the anterior transvaginal approach.

The diagnosis of rectocele can be made only by anamnesis and physical examination by experienced surgeons. However, sometimes, the gold standard to confirm the diagnosis and to reveal the status of rectocele is defecography, and the appearance is typical (Figure 1). Pelvic MRI or computed tomography and rectoscopy/colonoscopy are sometimes used for diagnosis. In the differential diagnosis, it should be remembered that it might be confused with other pelvic floor diseases such as cystocele and uterocele and perianal disorders such as rectal prolapse and hemorrhoidal disease. In appropriate patients in the initial treatment of the disease, conservative methods such as daily lifestyle changes, weight loss, avoidance of heavy lifting, treatment of constipation, and pelvic floor muscle exercise can be tried. ${ }^{8}$ When conservative treatments are inadequate, surgical treatment options are considered. There is no consensus on which

Table 3. Scoring system of the frequency of digitation, the intensity of straining, insufficient discharge and clinical symptoms of vaginal mass

\begin{tabular}{ll} 
Symptoms & Score \\
\hline Always/severe & 3 \\
Usually/moderate & 2 \\
Sometimes & 1 \\
None & 0
\end{tabular}

surgical method to choose. This situation generally varies according to the surgeon's experience and treatment plan for diseases associated with rectocele. ${ }^{9}$ In the selection of surgical technique, individual evaluation should be made. Individual factors such as additional pelvic floor diseases accompanying the rectocele, age of the patients, and whether they are in the reproductive period should be considered. The principles of surgery are to repair the weak point between the rectum and vagina, to reconstruct the anterior wall of the rectum and to restore the normal anatomy of the rectum in the defecation. Surgical methods include many methods with different success rates, such as transanal surgery, transvaginal surgery, transperineal mesh repair, stapled transanal rectal resection (STARR), and laparoscopic-assisted STARR. ${ }^{10,11,12,13,14}$ STARR was first described by Longo for rectocele treatment and is a transrectal operation that resects the submucosa and partially the muscular layer with the aid of the stapler for reducing the depth and width of the lower rectum..$^{15}$ This method is a new method developed in the last ten years and provides satisfactory treatment. ${ }^{16}$ In previous studies, it has been reported that sexual dysfunction and recurrence rates are high in patients who underwent primary repair by transvaginal route. ${ }^{17}$ Although most of the patients in our study were repaired in this way, we could not comment on this issue since the patients were not questioned for post-operative sexual dysfunction. However, in our study, recurrence was seen in only one of 65 patients (83\%) who underwent transvaginal repair. The transvaginal approach can be safely recommended for patients with isolated rectocele and required an additional gynecological operation. It is seen that the use of perineal prolene mesh repair method, which has gained more popularity in recent years and attracts attention with low recurrence rates, has been increasing and becoming widespread in our clinic (Figure 2). The main advantage of this method is that it eliminates the limitations of tissue repair, such as weak tissue strength and restores normal anatomical support without tension. ${ }^{18}$ No complications or recurrences have been observed in

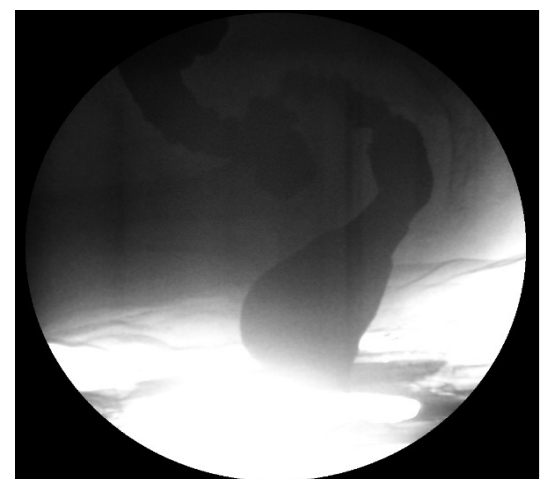

Figure 1. Defecography image of the anterior rectocele 


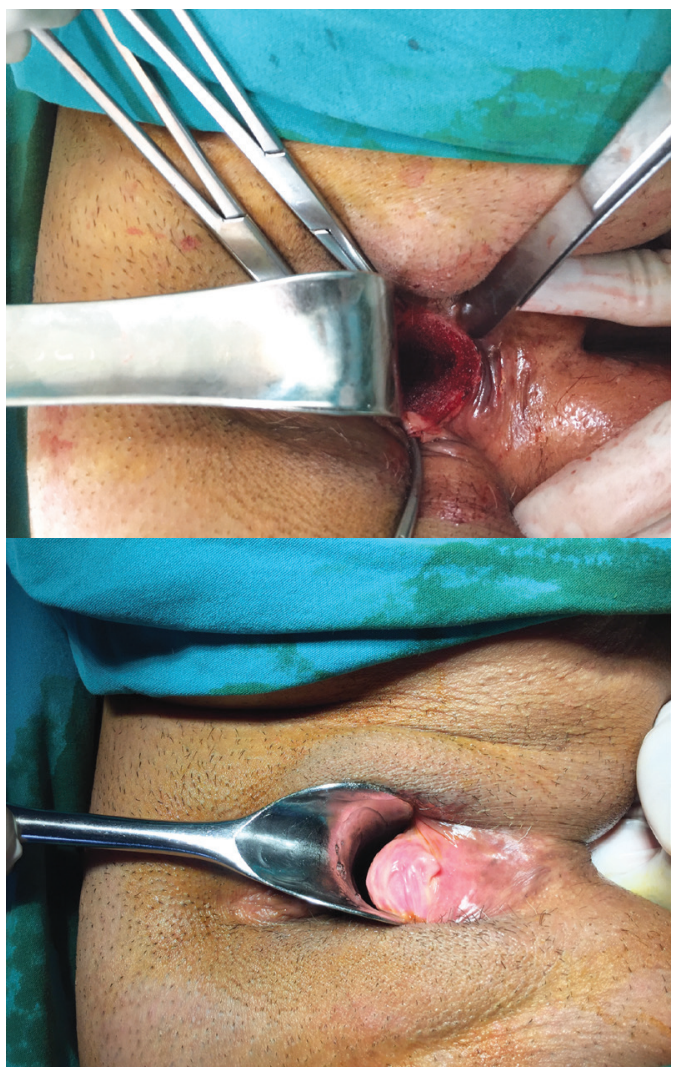

Figure 2. Rectocele repair with perineal prolene mesh (pre-operative, per-operative, and post-operative images in operation were sent separately.

any of the six patients we have used this technique so far. However, long-term results are still incomplete, and long follow-up is needed to evaluate mesh-related complications.

\section{Conclusion}

As a result, rectocele is a common disease in society, especially in patients with pelvic floor dysfunction. When appropriate diagnosis and early treatment plans are made by specific surgeons, it can be treated successfully with a low morbidity rate. It should be kept in mind that rectocele is a preventable disease to a certain extent, and it should be remembered that its incidence could be reduced by lifestyle changes.

\section{Ethics}

Ethics Committee Approval: This study was approved by Başkent University Institutional Review Board (Project No: KA 19/83 Date: 05/03/2019).

Informed Consent: Informed consent was obtained from all patients preoperatively.

Peer-review: External and internal peer-reviewed.

\section{Authorship Contributions}

Surgical and Medical Practices: H.Y., M.K., Concept: R.S., H.Y., Design: H.Y., Data Collection or Processing: M.K.,
Analysis or Interpretation: İ.M.A., Literature Search: R.S., H.Y., Writing: R.S.

Conflict of Interest: No conflict of interest was declared by the authors.

Financial Disclosure: The authors declared that this study received no financial support.

\section{References}

1. Dietz HP, Steensma AB. The role of child birth in the aetiology of rectocele. BJOG 2006;113:264-267.

2. Palit S, Bhan C, Lunniss PJ, Boyle DJ, Gladman MA, Knowles CH, et al. Evacuation proctography: a reappraisal of normal variability. Colorectal Dis 2014; 16:538-546.

3. Shi Y, Yu Y, Zhang X, Li Y. Transvaginal mesh and transanal resection to treat outlet obstruction constipation caused by rectocele. Med Sci Monit 2017;23:598-605

4. Philippa S, Roland M. Biomaterials in urinary incontinence and treatment of their complications. Indian J Urol 2010;26:221-229.

5. Christodoulou M, Papalois A, Mouzakis D, Zaoutsos S. Dynamic mechanical properties of tissue after long-term implantation of collagen and polypropylene meshes in animal models. Open Journal of Urology 2013;3:155-159.

6. Wijffels NA, Jones OM, Cunningham C, Bemelman, WA, Lindsey I. What are the symptoms of internal rectal prolapse? Colorectal Dis 2013;15:368373.

7. Watson SJ, Loder PB, Halligan S, Bartram CI, Kamm MA, Phillips RK. Transperineal repair of symptomatic rectocele with Marlex mesh: a clinical, physiological and radiologic assessment of treatment. J Am Coll Surg 1996; 183:257-261.

8. Chung SH, Kim WB. Various approaches and treatments for pelvic organ prolapse in women. J Menopausal Med 2018;24:155-162.

9. Zimmerman EF, Hayes RS, Daniels IR, Smart NJ, Warwick AM Transperineal rectocele repair: a systematic review. ANZ J Surg 2017;87:773-779

10. Mercer-Jones MA, Sprowson A, Varma JS. Outcome after transperineal mesh repair of rectocele: a case series. Dis Colon Rectum 2004;47:864868.

11. Ayav A, Bresler L, Brunaud L, Boissel P. Long-term results of transanal repair of rectocele using linear stapler. Dis Colon Rectum 2004;47:889894.

12. Petersen S, Hellmich G, Schuster A, Lehmann D, Albert W, Ludwig K. Stapled transanal rectal resection under laparoscopic surveillance for rectocele and concomitant enterocele. Dis Colon Rectum 2006;49:685689.

13. Mellgren A, Anzen B, Nilsson BY, Johansson C, Dolk A, Gillgren P. Results of rectocele repair: A prospective study. Dis Colon Rectum 1995;38:7-13.

14. Cundiff GW, Weidner AC, Visco AG, Addison WA, Bump RC. An anatomic and functional assessment of the discrete defect rectocele repair. Am J Obstet Gynecol 1998;179:1451-1456.

15. Gagliardi G, Pescatori M, Altomare DF, Binda GA, Bottini C, Dodi G, et al. Results, outcome predictors, and complications after stapled transanal rectal resection for obstructed defe $\neg$ cation. Dis Colon Rectum 2008;51:186-195.

16. Hasan HM, Hasan HM. Stapled transanal rectal resection for the surgical treat $\neg$ ment of obstructed defecation syndrome associated with rectocele and rec $\neg$ tal intussusception. ISRN Surg 2012;2012:652345.

17. Kahn MA, Stanton SL. Posterior colporrhaphy: its effects on bowel and sexual function. Br J Obstet Gynaecol 1997;104:82-86.

18. Leventoğlu S, Menteş BB, Bozkırlı B, Oğuz M. Rektoselde transperineal fasial sütür onarımla polipropilen mesh ile onarım sonuçlarının karşılaştırılması. Kolon Rektum Hast Derg 2007;17:9-15. 